\title{
Effect of gelation temperature on the properties of skim milk gels made from plant coagulants and chymosin
}

\author{
Cristina L.C. Esteves ${ }^{\mathrm{a}, \mathrm{b}, 1}$, John A. Lucey ${ }^{\mathrm{a}, *}$, Douglas B. Hyslop ${ }^{\mathrm{a}}$, Euclides M.V. Pires ${ }^{\mathrm{b}}$ \\ ${ }^{a}$ Department of Food Science, University of Wisconsin-Madison, 1605 Linden Drive, Madison, WI 53706-1565, USA \\ ${ }^{\mathrm{b}}$ Departamento de Bioquímica, Faculdade de Ciências e Tecnologia, Universidade de Coimbra, Apartado 3126, 3000 Coimbra, Portugal
}

Received 21 June 2002; accepted 3 May 2003

\begin{abstract}
Reconstituted skim milk was gelled at $25-40^{\circ} \mathrm{C}$ with the plant-origin coagulants from Cynara cardunculus $\mathrm{L}$. or Cynara humilis $\mathrm{L}$. or with fermentation-produced chymosin. Gel formation and ageing were monitored by low amplitude oscillatory rheology and confocal scanning laser microscopy. Arrhenius plots for the rate of milk gelation were also determined. Plant coagulants had shorter gelation time $\left(t_{\mathrm{g}}\right)$ at $25^{\circ} \mathrm{C}, 35^{\circ} \mathrm{C}$ and $40^{\circ} \mathrm{C}$, and higher initial rate of increase in $G^{\prime}$ values at all temperatures tested. The firmest gels at long ageing times were produced by chymosin at $30^{\circ} \mathrm{C}$ and $32^{\circ} \mathrm{C}$. At a gelation temperature of $25^{\circ} \mathrm{C}$, the differences in rheological and microstructural characteristics between plant coagulants and chymosin were considerable; plant coagulants had shorter $t_{\mathrm{g}}$ and higher $G^{\prime}$ values. For the lowest gelation temperatures, plant coagulants had smaller activation energy values for gelation. Most of the gelation results were similar between plant coagulants, but some differences were found in the values of $t_{\mathrm{g}}$, the rate of increase in $G^{\prime}$ and loss tangent parameter. The characteristics of gels produced with plant coagulants were influenced less by the changes in temperature compared with chymosin-produced gels, which may be an important consideration in using plant-origin coagulants in the production of cheeses with a wider range of gelation temperatures.
\end{abstract}

(C) 2003 Elsevier Ltd. All rights reserved.

Keywords: Gelation temperature; Plant coagulants; Rheology; Rennet coagulation; Cardunculus; Humilis; Chymosin; Confocal scanning laser microscopy

\section{Introduction}

The coagulants obtained from the flowers of Cynara sp. have been used in the South of Europe for more than 2000 years (Fox, 1993). Nowadays, the use of the coagulants of Cynara sp. is mostly restricted to the production of some Portuguese cheeses. Because of the unique characteristics of these types of cheeses, they have been designated Protected Designation of Origin by the European Union (EEC, 1996).

Gelation of milk, the crucial initial step in cheesemaking, is greatly influenced by temperature (Zoon, van Vliet, \& Walstra, 1988b). Gelation temperature may vary from $\sim 20^{\circ} \mathrm{C}$ to $40^{\circ} \mathrm{C}$, depending on the type of cheese being produced (Battistotti, Bottazzi, Piccinardi,

\footnotetext{
*Corresponding author. Tel.: + 1-608-265-1195; fax: + 1-608-2626872.

E-mail address: jalucey@facstaff.wisc.edu (J.A. Lucey).

${ }^{1}$ Present address: Department of Microbiology, University of Iowa, 3403 BSB, 51 Newton Road, Iowa City, IA 52242, USA.
}

\& Volpato, 1984). The gelation of milk is a result of two reactions; an enzymatic hydrolysis reaction and a physical aggregation of the coagulant-altered casein micelles. Both reactions are influenced by temperature, especially micelle aggregation, and they are expected to vary independently (van Hooydonk, Olieman, \& Hagedoorn, 1984). Coagulants act on casein at temperatures as low as $\sim 0^{\circ} \mathrm{C}$, but milk does not clot at temperatures below $\sim 18^{\circ} \mathrm{C}$ (Payens, 1989). In contrast, aggregation is very rapid at high temperature (e.g., $\geqslant 55^{\circ} \mathrm{C}$; Dalgleish, 1983).

Plant coagulants share many biochemical features with chymosin. Both chymosin and plant coagulants cleave the Phe ${ }_{105}-\mathrm{Met}_{106}$ bond of $\kappa$-casein (Macedo, Faro, \& Pires, 1993), but plant coagulants are more proteolytic and have broader specificity on $\alpha_{\mathrm{s} 1}{ }^{-}$and $\beta$-caseins than chymosin (Macedo et al., 1993). Cynara cardunculus L. coagulant contains two aspartic proteinases cardosin A and B; cardosin B is more proteolytic than cardosin A (Esteves, Veríssimo, Faro, \& Pires, 1995). A cardosin A-like enzyme was the only aspartic 
proteolytic enzyme found in Cynara humilis L. coagulant (Esteves, 1995).

Despite the importance of gelation temperature in the cheese-making process, there are very few reports on the effect of temperature on milk gelation using Cynara sp. coagulants (Christen \& Virasoro, 1935; Vieira de Sá \& Barbosa, 1972). Only the clotting time was considered in those studies and, to the best of our knowledge, there are no reports on the effect of temperature on the rheological properties of plant coagulant-induced gels.

The main objective of the present work was to study the effect of gelation temperature on the characteristics of skim milk gels produced by the plant coagulants, C. cardunculus $\mathrm{L}$. and C. humilis $\mathrm{L}$., in comparison to gels produced by chymosin.

\section{Material and methods}

\subsection{Materials}

Low heat bovine skim milk powder (SMP) was supplied by Dairy Farmers of America (Fresno, CA 93727, USA). The plant coagulants from C. cardunculus L. and $C$. humilis L. were obtained as described by Esteves, Lucey, and Pires (2001). The quantity of protein used in coagulation assays was 0.025 and $0.013 \mathrm{mg} \mathrm{mL}^{-1}$ of milk, for extracts from C. cardunculus L. and C. humilis L., respectively. The fermentationproduced chymosin used was Maxiren DS (DSM GistBrocades, 2600 MA Delft, The Netherlands) and its strength was 600 International Milk Clotting Units (IMCU mL ${ }^{-1}$ ) (IDF, 1997). Soybean trypsin inhibitor (STI), type I-S, (Lot. 30K 7020) was supplied by Sigma Chemical Co. (St Louis, MO 63178, USA).

\subsection{Preparation of milk samples}

SMP with a $7.05 \mathrm{mgg}^{-1}(\mathrm{w} / \mathrm{w})$ of undenatured whey protein nitrogen in SMP (Bradley et al., 1992) was reconstituted $(9 \%, \mathrm{w} / \mathrm{w})$ in an aqueous solution with $\mathrm{CaCl}_{2}\left(0.1 \mathrm{mg} \mathrm{mL}^{-1}\right) ; \mathrm{NaN}_{3}\left(0.2 \mathrm{mg} \mathrm{mL}^{-1}\right)$ and STI $\left(0.15 \mathrm{mg} \mathrm{mL}^{-1}\right)$ were added to prevent bacterial growth and inhibit plasmin activity, respectively. Milk was reconstituted at $32^{\circ} \mathrm{C}$ for $2 \mathrm{~h}$ with gentle agitation using a magnetic stirring unit, and then left at $22^{\circ} \mathrm{C}$ for at least $1 \mathrm{~h}$ before the rheology or microscopy experiments.

\subsection{Rheological assays}

Milk gels are viscoelastic and their small deformation rheological properties can be determined by low amplitude dynamic oscillation (Zoon, van Vliet, \& Walstra, 1988a). A Universal Dynamic Spectrometer, Paar Physica UDS 200 (Physica Messtechnik GmbH, D-70567, Stuttgart, Germany) was used. The measuring geometry (MK 25) consisted of a cone (diam. $75 \mathrm{~mm}$, angle $2^{\circ}$ ) and a plate.

Before comparing the gelation properties of $C$. cardunculus L., C. humilis L. and chymosin, the same gelation time $\left(t_{\mathrm{g}} ; \sim 19 \mathrm{~min}\right)$ was ascertained for all three coagulants in milk gelation experiments conducted at $32^{\circ} \mathrm{C}$. The amounts of each coagulant necessary to obtain a $t_{\mathrm{g}}$ of $\sim 19 \mathrm{~min}$ at $32^{\circ} \mathrm{C}$, was also used in the experiments at the other temperatures. Gelation assays were performed at $25^{\circ} \mathrm{C}, 30^{\circ} \mathrm{C}, 32^{\circ} \mathrm{C}, 35^{\circ} \mathrm{C}$ and $40^{\circ} \mathrm{C}$ and were followed for $\sim 16, \sim 8.5, \sim 6, \sim 4$ and $\sim 3 \mathrm{~h}$, respectively after the addition of a coagulant to milk. Gels produced at $30^{\circ} \mathrm{C}, 32^{\circ} \mathrm{C}$ and $35^{\circ} \mathrm{C}$ were tested every $2 \mathrm{~min}$ during the first $30 \mathrm{~min}$ of assay, and then every $30 \mathrm{~min}$ in the rest of the experiment. In the assays at $40^{\circ} \mathrm{C}$, gels were tested every $2 \mathrm{~min}$ during the first $30 \mathrm{~min}$ of the assay, and then every $15 \mathrm{~min}$ for the rest of the experiment. At $25^{\circ} \mathrm{C}$, gels were tested every $30 \mathrm{~min}$ during the complete experimental run. Before starting the assays, milk was equilibrated for $15 \mathrm{~min}$ at the assay temperature $\left(25^{\circ} \mathrm{C}, 30^{\circ} \mathrm{C}, 32^{\circ} \mathrm{C}, 35^{\circ} \mathrm{C}\right.$ or $\left.40^{\circ} \mathrm{C}\right), 25.5 \mu \mathrm{L}$ of previously diluted enzyme was added to $4.25 \mathrm{~mL}$ of milk, which was then mixed thoroughly and the mixture immediately transferred to the plate of the rheometer. The exposed edge of the cone and plate geometry was covered with vegetable oil to prevent dehydration of the sample. In the gelation experiments, samples were oscillated at a frequency of $0.1 \mathrm{~Hz}$ and the strain applied was 0.03 , which is within the linear viscoelastic region for rennet gels (Zoon et al., 1988a).

In the present work, gelation time $\left(t_{\mathrm{g}}\right)$ was arbitrarily considered as the time necessary for the gel to reach a storage modulus $\left(G^{\prime}\right)$ value of $0.5 \mathrm{~Pa}$. This was considered the first reliable increase in $G^{\prime}$ that exceeded the signal noise, obtained when the milk started to gel in our experimental conditions.

\subsection{Rate of gelation of milk-Arrhenius plots}

The gelation rate parameter was obtained from the maximum rate of increase in $G^{\prime}$ over time, $\left(\mathrm{d} G^{\prime} / \mathrm{d} t\right)_{\max }$. An Arrhenius plot gives the dependence of a reaction rate constant, $K$, on temperature as:

$K=A \mathrm{e}^{-E_{\mathrm{a}} / R T}$,

where $K$ is the reaction rate constant at a given temperature, $T\left({ }^{\circ} \mathrm{C}\right), A$ is an empirical constant, $E_{\mathrm{a}}$ is the activation energy and $R$ is the gas constant. $E_{\mathrm{a}}$ may be defined as the minimum energy that a reactant molecule must have in order to be converted to a product molecule (e.g., Whitaker, 1994).

\subsection{Confocal scanning laser microscopy (CSLM)}

Acridine orange was the fluorescent protein dye used in confocal scanning laser microscopy (CSLM) 
experiments. Acridine orange was dissolved in distilled water and added to reconstituted milk $(0.03 \%, \mathrm{w} / \mathrm{v})$ at room temperature and held for $15 \mathrm{~min}$ at the temperature used for gelation $\left(25^{\circ} \mathrm{C}\right.$ or $\left.32^{\circ} \mathrm{C}\right)$. The coagulant was added to milk just before it was transferred to a slide with a cavity. A coverslip was placed over the sample and the slides were then held at $25^{\circ} \mathrm{C}$ or $32^{\circ} \mathrm{C}$ in an incubator (Model 650F, Fisher Scientific, Hanover, IL 601333). Gels were examined $2 \mathrm{~h}$ after $t_{\mathrm{g}}$ and at the end of the experiment $\left(\sim 16\right.$ and $\sim 6 \mathrm{~h}$ for gels made at $25^{\circ} \mathrm{C}$ and $32^{\circ} \mathrm{C}$, respectively), using a Bio-Rad MRC 1024 CSLM (Hemel, Hempstread, UK HP2 7TD) attached to an inverted Nikon Eclipse TE 300 microscope with heated stage. The same concentration of coagulant was used in the CSLM experiments as in the rheological assays. For each sample, slides were made in duplicate and at least five representative fields were examined.

\subsection{Statistical analysis}

The mixed model procedure, Proc Mixed was used to analyse the results. The $t_{\mathrm{g}}$ results were log-transformed because they did not follow a normal distribution. Means were compared using the Tukey-Kramer procedure. Significance was indicated by $p<0.05$. Each experiment was repeated 3 times. All statistical analyses were conducted using the SAS (1999) program.

\section{Results}

\subsection{Gelation time}

There was a decrease in $t_{\mathrm{g}}$ with increasing temperature, a result that occurred with all coagulants $\left(p<0.0001\right.$; Table 1). The $t_{\mathrm{g}}$ was set (experimentally) to be $\sim 19 \mathrm{~min}$ at $32^{\circ} \mathrm{C}$, for all coagulants. However, $t_{\mathrm{g}}$ varied differently with temperature for plant coagulants and chymosin. At $25^{\circ} \mathrm{C}$ and $35^{\circ} \mathrm{C}, t_{g}$ for chymosin was significantly longer than for both plant coagulants, which had similar $t_{\mathrm{g}}$. At $30^{\circ} \mathrm{C}$, all coagulants had similar $t_{\mathrm{g}}$. At the highest temperature studied $\left(40^{\circ} \mathrm{C}\right)$ chymosin showed the longest $t_{\mathrm{g}}, C$. humilis $\mathrm{L}$. the shortest and the value for $C$. cardunculus $\mathrm{L}$. was in between $(p=0.0002)$.

\subsection{Gelation and small deformation rheological properties}

For all coagulants, gelation proceeded faster with increasing temperature (Fig. 1). Gels produced at $25^{\circ} \mathrm{C}$ and $40^{\circ} \mathrm{C}$ were the slowest and fastest, respectively, in reaching a steady increase in $G^{\prime}$ values (Fig. 1). During the initial stage of gelation, gels produced by plant coagulants tended to have higher $G^{\prime}$ values than chymosin.

Table 1

Effect of gelation temperature on the gelation time, storage modulus ${ }^{1}\left(G^{\prime}\right)$ and $\tan \delta^{2}$ of milk gels induced by the coagulants from Cynara cardunculus L., Cynara humilis L. or by chymosin

\begin{tabular}{|c|c|c|c|c|}
\hline \multirow[t]{2}{*}{ Rheological parameter } & \multirow[t]{2}{*}{ Temperature $\left({ }^{\circ} \mathrm{C}\right)$} & \multicolumn{3}{|l|}{ Type of coagulant } \\
\hline & & Cynara cardunculus $\mathrm{L}$. & Cynara humilis $\mathrm{L}$. & Chymosin \\
\hline \multirow[t]{5}{*}{ Gelation time (s) } & 25 & $2350(46)^{\mathrm{a}, \mathrm{A}}$ & $2413(31)^{\mathrm{a}, \mathrm{A}}$ & $4547(104)^{\mathrm{a}, \mathrm{B}}$ \\
\hline & 30 & $1342(26)^{\mathrm{b}, \mathrm{A}}$ & $1489(98)^{\mathrm{b}, \mathrm{A}}$ & $1583(61)^{\mathrm{b}, \mathrm{A}}$ \\
\hline & 32 & $1136(39)^{\mathrm{c}, \mathrm{A}}$ & $1112(37)^{\mathrm{c}, \mathrm{A}}$ & $1123(44)^{\mathrm{c}, \mathrm{A}}$ \\
\hline & 35 & $846(39)^{\mathrm{d}, \mathrm{A}}$ & $816(26)^{\mathrm{d}, \mathrm{A}}$ & $1118(42)^{\mathrm{c}, \mathrm{B}}$ \\
\hline & 40 & $688(35)^{\mathrm{e}, \mathrm{A}}$ & $579(13)^{\mathrm{e}, \mathrm{B}}$ & $965(37)^{\mathrm{d}, \mathrm{C}}$ \\
\hline \multirow[t]{5}{*}{ Storage modulus, $G^{\prime}(\mathrm{Pa})$} & 25 & $53.9(1.0)^{\mathrm{a}, \mathrm{A}}$ & $61.7(2.3)^{\mathrm{a}, \mathrm{B}}$ & $49.2(0.2)^{\mathrm{a}, \mathrm{C}}$ \\
\hline & 30 & $65.8(1.6)^{\mathrm{b}, \mathrm{A}}$ & $68.5(2.5)^{\mathrm{b}, \mathrm{A}}$ & $82.5(2.7)^{\mathrm{b}, \mathrm{B}}$ \\
\hline & 32 & $69.2(2.6)^{\mathrm{b}, \mathrm{A}}$ & $70.0(2.4)^{\mathrm{b}, \mathrm{A}}$ & $83.1(1.0)^{\mathrm{b}, \mathrm{B}}$ \\
\hline & 35 & $64.9(3.2)^{\mathrm{b}, \mathrm{A}, \mathrm{B}}$ & $62.6(1.3)^{\mathrm{a}, \mathrm{B}}$ & $69.6(1.0)^{\mathrm{c}, \mathrm{A}}$ \\
\hline & 40 & $50.1(0.6)^{\mathrm{a}, \mathrm{A}}$ & $52.3(1.7)^{\mathrm{c}, \mathrm{A}}$ & $51.1(1.6)^{\mathrm{a}, \mathrm{A}}$ \\
\hline \multirow[t]{5}{*}{$\operatorname{Tan} \delta\left(\times 10^{-2}\right)$} & 25 & $22.7(0.00)^{\mathrm{a}, \mathrm{A}}$ & $23.2(0.06)^{\mathrm{a}, \mathrm{B}}$ & $23.2(0.06)^{\mathrm{a}, \mathrm{B}}$ \\
\hline & 30 & $29.0(0.15)^{\mathrm{b}, \mathrm{A}}$ & $29.6(0.12)^{\mathrm{b}, \mathrm{B}}$ & $30.6(0.10)^{\mathrm{b}, \mathrm{C}}$ \\
\hline & 32 & $32.3(0.06)^{\mathrm{c}, \mathrm{A}}$ & $33.4(0.15)^{\mathrm{c}, \mathrm{B}}$ & $33.5(0.12)^{\mathrm{c}, \mathrm{B}}$ \\
\hline & 35 & $38.8(0.00)^{\mathrm{d}, \mathrm{A}}$ & $39.4(0.06)^{\mathrm{d}, \mathrm{B}}$ & $39.9(0.25)^{\mathrm{d}, \mathrm{B}}$ \\
\hline & 40 & $49.7(0.20)^{\mathrm{e}, \mathrm{A}}$ & $50.2(0.25)^{\mathrm{e}, \mathrm{A}}$ & $50.4(0.29)^{\mathrm{e}, \mathrm{A}}$ \\
\hline
\end{tabular}

Values are means of three replicates (standard deviation in brackets).

Means with different superscripts within each coagulant (lower case) and within each temperature (upper case), for each of the parameters measured, are different $(p<0.05)$.

${ }^{1}$ Measurements were taken $\sim 16, \sim 8.5, \sim 6, \sim 4$ and $\sim 3 \mathrm{~h}$ after coagulant addition to milk at the gelation temperatures $25^{\circ} \mathrm{C}, 30^{\circ} \mathrm{C}, 32^{\circ} \mathrm{C}, 35^{\circ} \mathrm{C}$ and $40^{\circ} \mathrm{C}$, respectively. This corresponded to a steady increase in $G^{\prime}$ values of milk gels.

${ }^{2} \operatorname{Tan} \delta$ was obtained at a frequency of $0.1 \mathrm{~Hz}$. 

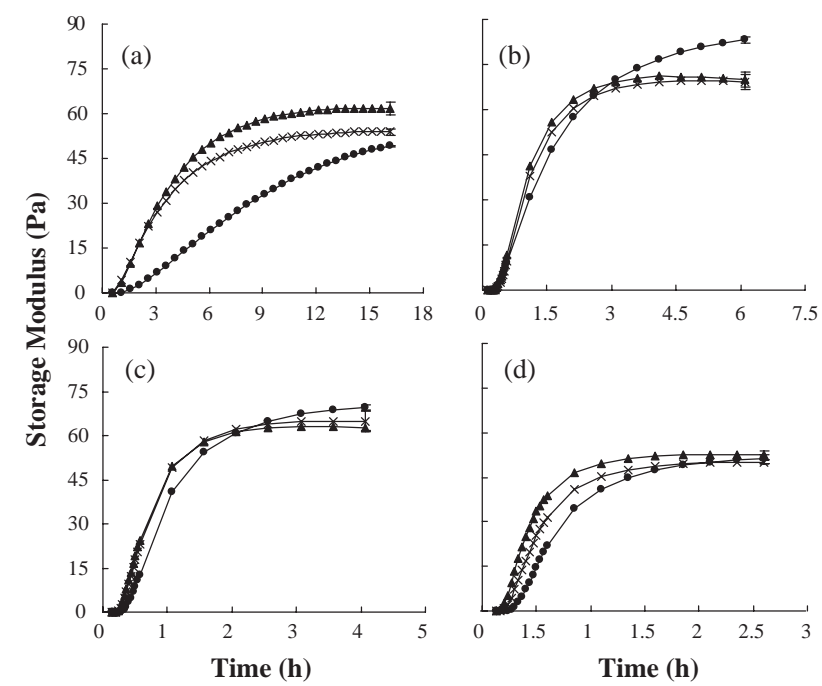

Fig. 1. Storage modulus $\left(G^{\prime}\right)$ as a function of time for skim milk gels obtained at $25^{\circ} \mathrm{C}$ (a), $32^{\circ} \mathrm{C}$ (b), $35^{\circ} \mathrm{C}$ (c) and $40^{\circ} \mathrm{C}$ (d) using the coagulants from $C$. cardunculus $\mathrm{L} .(\times)$, C. humilis L. $(\mathbf{\Delta})$ or chymosin ( ). Time zero corresponds to addition of coagulant to milk. Values are means $(n=3)$ and vertical bars are the standard deviations for the last data points.

At the end of the experiments, $G^{\prime}$ values were roughly similar for plant coagulants and chymosin (Table 1). The highest $G^{\prime}$ values were observed at $30^{\circ} \mathrm{C}$ and $32^{\circ} \mathrm{C}$ and the lowest $G^{\prime}$ values at $25^{\circ} \mathrm{C}$ and $40^{\circ} \mathrm{C}$; only at $25^{\circ} \mathrm{C}$, gels produced with $C$. humilis $\mathrm{L}$. did not follow this trend. For the several temperatures tested, chymosin-induced gels exhibited the largest difference between the $G^{\prime}$ values at the end of the experiment. At $25^{\circ} \mathrm{C}$, the $G^{\prime}$ values of chymosin where lower than those of plant coagulants, even after $\sim 16 \mathrm{~h}$ of gelation $(p<0.005)$.

C. cardunculus $\mathrm{L}$. and C. humilis $\mathrm{L}$. produced similar gelation curves at $30^{\circ} \mathrm{C}, 32^{\circ} \mathrm{C}$ and $35^{\circ} \mathrm{C}$ (Fig. 1). At $25^{\circ} \mathrm{C}$, both plant coagulants had very similar gelation profiles during the initial stage of gelation. However, $G^{\prime}$ values at the end of the experiment were higher for $C$. humilis L. than for $C$. cardunculus L. (Table $1 ; p=0.004$; Fig. 1). At $40^{\circ} \mathrm{C}$, during the initial stage of gelation, $G^{\prime}$ values increased faster for $C$. humilis L. $(p<0.034)$ than the values for $C$. cardunculus $\mathrm{L}$., but at the end of the experiment $G^{\prime}$ values were not significantly different between the two plant coagulants.

Some significant differences were obtained within coagulants for the values of loss tangent $(\tan \delta)$ at the end of gelation, although the differences in absolute values were very small (Table 1 ). It should be noticed, that at three gelation temperatures $\left(25^{\circ} \mathrm{C}, 32^{\circ} \mathrm{C}\right.$ and $35^{\circ} \mathrm{C}$ ), the values of $\tan \delta$ for $C$. cardunculus L. were lower than those obtained for $C$. humilis L. and chymosin $(p<0.02)$, and no differences were obtained between the two latter coagulants. At $40^{\circ} \mathrm{C}$, there were no differences in $\tan \delta$ values among any of the

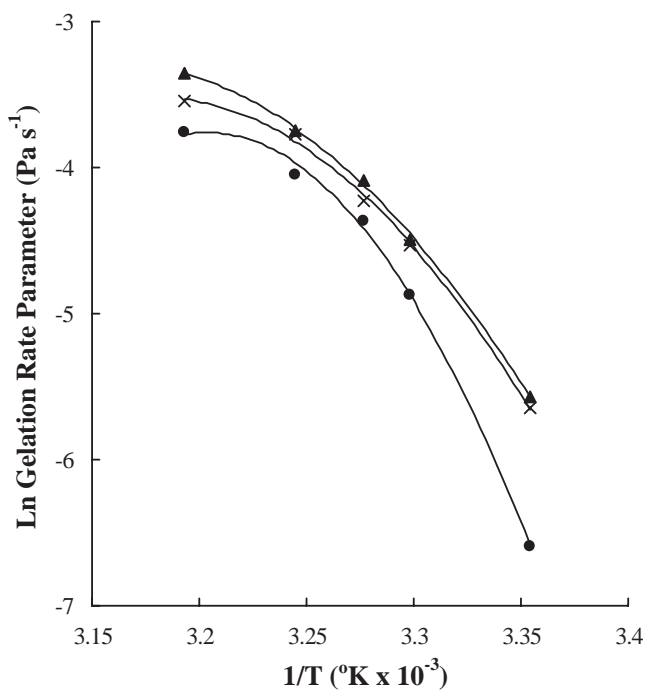

Fig. 2. Arrhenius plot of the gelation rate parameter for $C$. cardunculus $\mathrm{L} .(\times)$, C. humilis L. $(\mathbf{\Lambda})$ and chymosin $(\bullet)$. The gelation rate parameter was the maximum $\mathrm{d} G^{\prime} / \mathrm{d} t$ value obtained from the milk gelation profiles.

coagulants. Tan $\delta$ varied considerably with temperature, increasing in gels made at high temperature $(p<0.0001)$.

\subsection{Arrhenius plots of gelation rate}

We used the value of $\left(\mathrm{d} G^{\prime} / \mathrm{d} t\right)_{\max }$ as our gelation rate parameter. It is arguable that the slope of a plot of $G^{\prime}$ vs. $t$, at least during the initial rapid increase in the $G^{\prime}$ vs. $t$ curve, provides a measure of the rate of gelation of casein micelles. An Arrhenius plot for the $\left(\mathrm{d} G^{\prime} / \mathrm{d} t\right)_{\max }$ is shown in Fig. 2. The Arrhenius plots for plant coagulants, as well as for chymosin, were curved. This is consistent with the temperature dependence of flocculation rate constant for aggregation of casein micelles (Dalgleish, 1983). For lower temperatures, the slope of the curve for chymosin-induced gelation was much steeper than the curves for plant coagulants; consequently, the activation energy for gelation, $\left(E_{\mathrm{a}}\right)_{\mathrm{gel}}$, was lower for plant coagulants. For all coagulants, the values of $\left(E_{\mathrm{a}}\right)_{\text {gel }}$ decreased as temperature increased (Fig. 2).

\subsection{Confocal scanning laser microscopy}

Micrographs were obtained at $25^{\circ} \mathrm{C}$ and $32^{\circ} \mathrm{C}, 2 \mathrm{~h}$ after $t_{\mathrm{g}}$ and also at the end of the experiment $(\sim 16$ and $\sim 6 \mathrm{~h}$ at $25^{\circ} \mathrm{C}$ and $32^{\circ} \mathrm{C}$, respectively). Fig. 3 shows micrographs that were obtained from gels made with chymosin and $C$. humilis $\mathrm{L}$., which was representative of both plant coagulants. At $25^{\circ} \mathrm{C}, 2 \mathrm{~h}$ after $t_{\mathrm{g}}\left(G^{\prime} \sim 25 \mathrm{~Pa}\right)$, plant gels appeared to be fairly homogeneous with small 
pores and the protein network appeared very interconnected (Fig. 3a). In contrast, the casein network structure of chymosin-induced gels $\left(G^{\prime} \sim 8 \mathrm{~Pa}\right)$ was coarse with a few large pores (Fig. 3b). Dense clusters, or strands of aggregated protein particles, could be detected as well. At the end of gelation $(\sim 16 \mathrm{~h}$ after coagulant addition to milk) gels produced by chymosin (Fig. 3d) or plant coagulants (Fig. 3c) were similar, as were the microstructures of chymosin-induced gels and plant gels at $32^{\circ} \mathrm{C}$ (Figs. 3e-h). Gels produced at $32^{\circ} \mathrm{C}$ (Figs. 3e-h) had larger pores than at $25^{\circ} \mathrm{C}$ (Figs. 3a-d), except for chymosin gels examined $2 \mathrm{~h}$ after $t_{\mathrm{g}}$ (Figs. $3 \mathrm{~b}$ and f).

\section{Discussion}

For all coagulants, an increase in the gelation temperature resulted in faster milk gelation; $t_{\mathrm{g}}$ was shorter and gels had an initial faster rate of increase in $G^{\prime}$ (Fig. 1). The magnitude of $G^{\prime}$ values depends on the number and strength of bonds between casein particles,
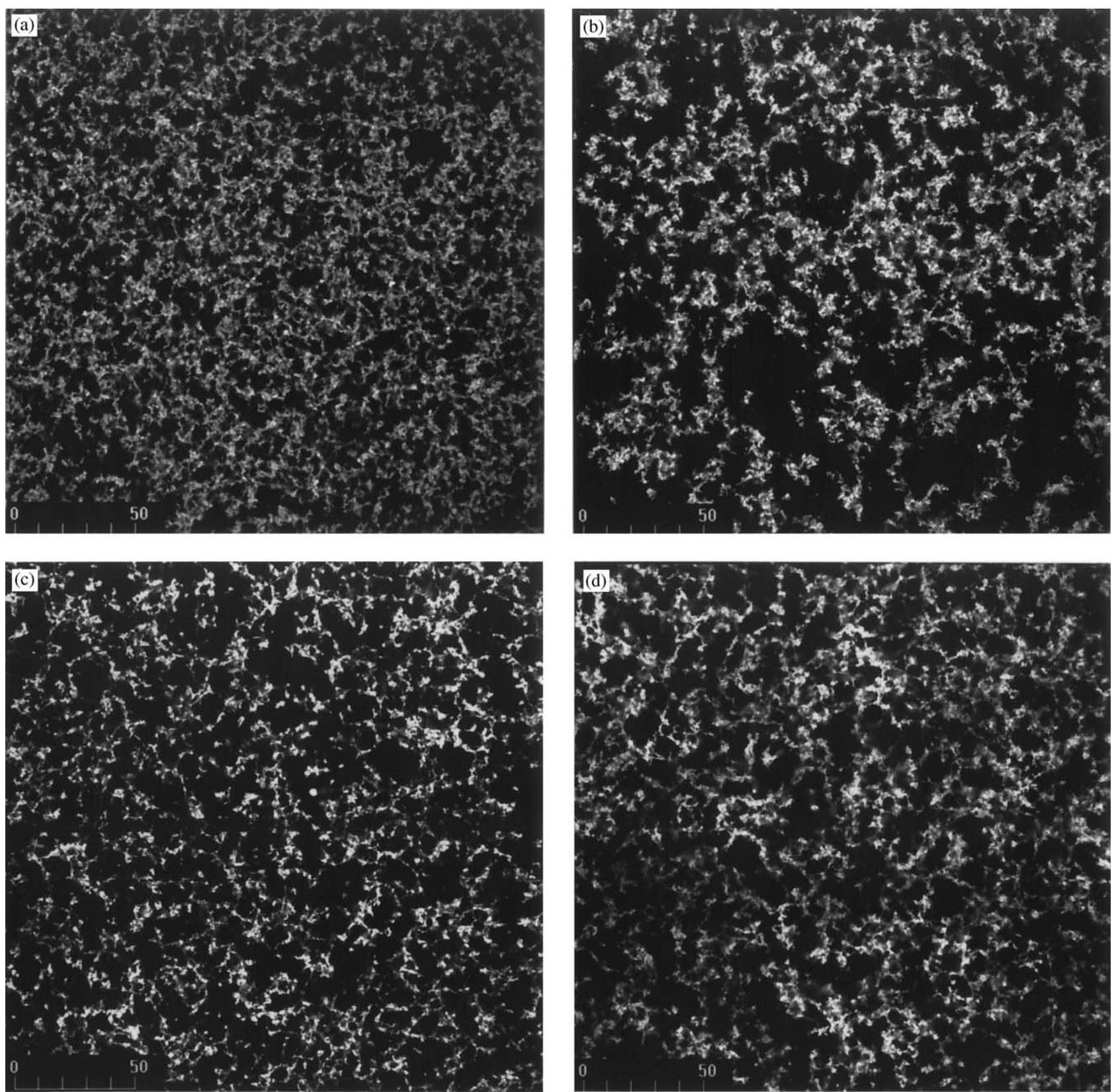

Fig. 3. Confocal scanning laser micrographs of skim milk gels at $25^{\circ} \mathrm{C}(\mathrm{a}-\mathrm{d})$ and $32^{\circ} \mathrm{C}(\mathrm{e}-\mathrm{h})$ induced by $C$. humilis $\mathrm{L}$. (a, c, e, g) or chymosin (b, d, f, h). Micrographs were taken $2 \mathrm{~h}$ after gelation time (a, b, e, f) and at the end of gelation experiment $\left(\sim 16\right.$ and $\sim 6 \mathrm{~h}$ at $25^{\circ} \mathrm{C}$ and $32^{\circ} \mathrm{C}$, respectively; c, $\mathrm{d}, \mathrm{g}, \mathrm{h})$. Protein matrix is white and dark areas are pores. Scale bar $=50 \mu \mathrm{m}$. 

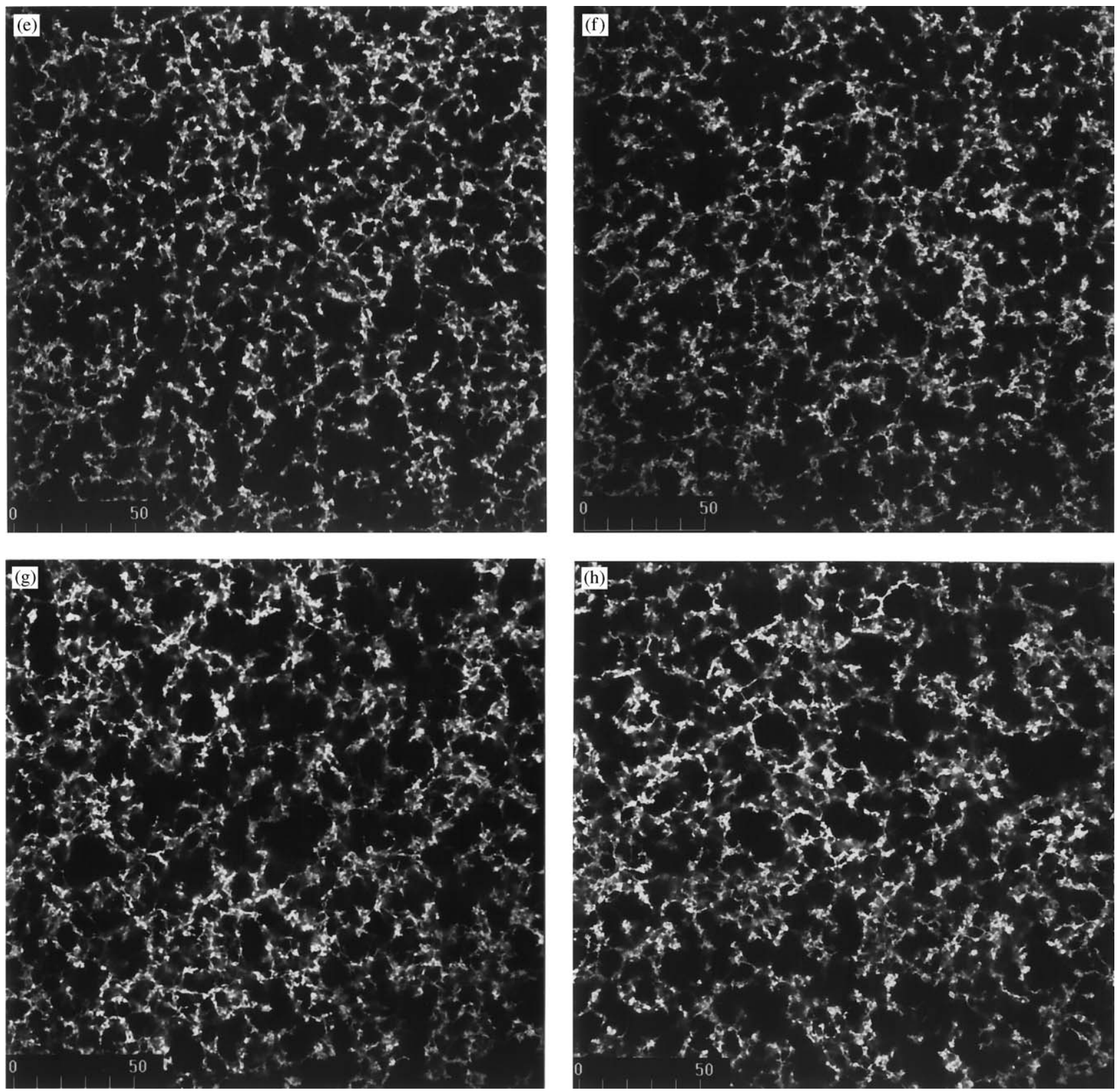

Fig. 3 (continued).

and also on the structure and spatial distribution of strands of casein in the gel network (Zoon et al., 1988a; van Vliet, 2000). In coagulant-induced gels, the rate of increase in $G^{\prime}$ values after $t_{\mathrm{g}}$ is considered to be due to rearrangements and fusion of casein particles (van Vliet, 2000) and to incorporation of more casein particles.

Using calf rennet as coagulant, Zoon et al. (1988b) observed that the rate of rearrangements for gels formed at high temperature (e.g. $40^{\circ} \mathrm{C}$ ) was greater, interactions between casein particles were weaker and the apparent plateau in $G^{\prime}$ values was reached earlier. Also, there are some indications that the casein networks of various types of milk gels formed at high temperature are less inter-connected, and have dense clusters of aggregated casein particles that may be associated with extensive particle rearrangements (Lagoueyte, Lablee, Lagaude, \& Tarodo de la Fuente, 1994; Lucey, van Vliet, Grolle, Geurts, \& Walstra, 1997). These may be possible explanations for the fast initial rate of increase in $G^{\prime}$ values and the relatively low $G^{\prime}$ values at the end of our experiments (Fig. 1; Table 1). These results correlate well with those obtained for $\tan \delta$ at the end of gelation, because gels formed at higher temperature tend to be more viscous-like. For all coagulants, increasing the temperature resulted in gels with significantly increased $\tan \delta$ values at the end of gelation. In milk gels, an 
increase in $\tan \delta$ values has been associated with enhanced syneresis behaviour of gels as well as rearrangements of the network (van Vliet, van Dijk, Zoon, \& Walstra, 1991; Mellema, 2000). This also indicates that changing gelation temperature not only changes the stiffness $\left(G^{\prime}\right)$ of the network, but also alters the viscoelastic character of the matrix.

It is commonly accepted that $\kappa$-casein exists primarily at the surface of micelles and is largely responsible for micelle stability (Holt \& Horne, 1996; Walstra, 1999). However, some regions of $\alpha_{\mathrm{s}}$ - or $\beta$-caseins may also be close to the micelle surface (Heth \& Swaisgood, 1982; Donnelly, McNeill, Buchheim, \& McGann, 1984; Dalgleish, Horne, \& Law, 1989; Diaz, Gouldsworthy, \& Leaver, 1996) and contribute to electrostatic repulsion between casein micelles. The effect of removing these portions of $\alpha_{\mathrm{s}^{-}}$or $\beta$-caseins by the coagulants could ultimately help in the gelation process, possibly by enhancing the initial destabilisation of casein micelles, and also by increasing the flexibility or the susceptibility of caseins to undergo faster rearrangements in gels. Both chymosin and plant coagulants have the ability to cleave some sites on $\alpha_{\mathrm{s} 1^{-}}$and $\beta$-caseins (Carles \& RibadeauDumas, 1985; Macedo et al., 1996; Ramalho-Santos, Veríssimo, Faro, \& Pires, 1996; Simões, 1998; Silva, Barros, \& Malcata, 2002) that may be important to maintain micelle stability (Berry \& Creamer, 1975; Creamer, 1976; Kumosinski, Brown, \& Farrell, 1993). However, Macedo et al. (1996) showed that chymosin and plant coagulants had some differences in specificity and/or velocity of hydrolysis of casein bonds. At the same experimental conditions at $30^{\circ} \mathrm{C}$, plant coagulants and chymosin had similar specificity towards $\beta$-casein, but plant coagulants hydrolysed peptide bonds on $\beta$ casein faster than chymosin; on $\alpha_{\mathrm{s} 1}$-casein, plant coagulants attacked the $\mathrm{C}$-terminal region but chymosin did not (Carles \& Ribadeau-Dumas, 1984; Macedo et al., 1996). In the range of temperatures $25-40^{\circ} \mathrm{C}$ that we used, Garnier (1963) and van Hooydonk et al. (1984) determined the activation energy for proteolysis $\left(E_{\mathrm{a}}\right)_{\text {prot }}$ using chymosin and commercial rennet, respectively. Faro (1991) studied the proteolytic activity of $C$. cardunculus L. on azocasein. We recalculated and replotted Faro's data in an Arrhenius plot (data not shown). It appears that plant coagulant enzymes yield $\left(E_{\mathrm{a}}\right)_{\text {prot }}$ values that increase with temperature, from a value of $\sim 20 \mathrm{~kJ} \mathrm{~mol}^{-1}$ at $10^{\circ} \mathrm{C}$ to $\sim 75 \mathrm{~kJ} \mathrm{~mol}^{-1}$ when temperature approaches $50^{\circ} \mathrm{C}$. The $\left(E_{\mathrm{a}}\right)_{\text {prot }}$ values for chymosin and commercial rennet $\left(\sim 25-30 \mathrm{~kJ} \mathrm{~mol}^{-1}\right)$ obtained by Garnier (1963) and van Hooydonk et al. (1984) did not change with temperature. In our case, when the temperature was $25^{\circ} \mathrm{C}$ or higher, the $\left(E_{\mathrm{a}}\right)_{\text {prot }}$ for plant coagulants was greater than for chymosin. Even though it is a precarious matter to try to match $E_{\mathrm{a}}$ values for proteolysis with actual energy equivalents for a process as complex as we are investigating here, it would appear that the larger $\left(E_{\mathrm{a}}\right)_{\text {prot }}$ values for plant coagulants are associated with extra proteolysis, i.e. plant coagulants cleave more bonds on casein micelles than chymosin.

During the initial stages of gelation, at all the temperatures used to form gels, plant coagulants tended to have higher values for both $G^{\prime}$ and the rate of increase in $G^{\prime}$ than gels made with chymosin; we have also observed such pattern in other studies where milk was only gelled at $32^{\circ} \mathrm{C}$ (Esteves et al., 2001). Interpretation of the temperature dependence of rate of change in $G^{\prime}$ is more complex than the temperature dependence of the rate of proteolysis. While it is arguable that the rate of proteolysis is not greatly affected by gelation, the reverse argument, that gelation is not greatly affected by proteolysis, is less tenable. Since proteolysis precedes gelation, its rate may well affect the latter's rate. If it is an uncertain matter to try to match proteolysis $E_{\mathrm{a}}$ values with actual energy equivalents, it is arguable that it is even less tenable to try to match gelation $E_{\mathrm{a}}$ values with energy equivalents. With these qualifications, we argue the following. The temperature where the differences between coagulants were more pronounced and could be easily observed using CSLM was $25^{\circ} \mathrm{C}$. At this, the lowest temperatures we measured, rate of change in $G^{\prime}$ (results not shown) were much larger for plant coagulants-treated micelles than for chymosintreated ones. The corresponding activation energy values for gelation $\left(E_{\mathrm{a}}\right)_{\mathrm{gel}}$ for plant coagulant-treated micelles were smaller, indicating that plant coagulanttreated micelles must overcome a smaller energy barrier in order to gel compared to chymosin-treated micelles. The lower $\left(E_{\mathrm{a}}\right)_{\text {gel }}$ values for plant coagulant treated micelles were consistent, with the suggestion that additional proteolysis (on $\alpha_{\mathrm{s} 1}{ }^{-}$and $\beta$-caseins) might reduce the barrier that micelles must overcome in order to gel. Low temperature induces conformational changes on micelles, and is likely to increase the accessibility of coagulant enzymes to caseins (Berry \& Creamer, 1975; Kumosinski et al., 1993). At $25^{\circ} \mathrm{C}$ we observed a different trend when gels were reaching a steady state increase in $G^{\prime}$ values compared to Zoon et al. (1988b), but the conditions they used to reconstitute the milk were different. In additional experiments, we followed the same procedures described by Zoon et al. (1988b) for the reconstitution of milk, and we obtained a similar pattern (results not shown).

With a few exceptions, the gelation results obtained with $C$. cardunculus $\mathrm{L}$. and $C$. humilis $\mathrm{L}$. were generally similar, likely due to their similar enzymatic content. At a gelation temperature of $25^{\circ} \mathrm{C}$, although $t_{\mathrm{g}}$ values for both coagulants were similar, C. cardunculus L. had lower $G^{\prime}$ values at the end of the experiment. Since C. cardunculus $\mathrm{L}$. has broader proteolytic activity, during the later part of the gelation process additional proteolysis may have occurred due to increased 
accessibility of peptide bonds on casein to cardosin B. At a gelation temperature of $40^{\circ} \mathrm{C}$, C. cardunculus $\mathrm{L}$. had longer $t_{\mathrm{g}}$ values than $C$. humilis $\mathrm{L}$. Since $C$. cardunculus $\mathrm{L}$. is more proteolytic than $C$. humilis $\mathrm{L}$., it is likely that at high temperature there was excessive proteolysis, probably caused by cardosin B. This may have adverse effects on gelation properties. Another important result was that $\tan \delta$ values at the end of gelation experiments tended to be similar for gels produced from $C$. humilis $\mathrm{L}$. and chymosin, but different from those produced from $C$. cardunculus $\mathrm{L}$.

\section{Conclusions}

Gelation temperature had a significant impact on the properties of gels produced by plant coagulants and chymosin. At the beginning of gelation, plant coagulants produced gels with higher rate of increase in $G^{\prime}$ values than chymosin, and most of the $t_{\mathrm{g}}$ values were also shorter for plant coagulants. Only a few differences were also observed between $C$. cardunculus $\mathrm{L}$. and C. humilis $\mathrm{L}$.

The differences observed between plant coagulants and chymosin may have some implications in cheesemaking technology. At low temperature $\left(25^{\circ} \mathrm{C}\right)$, the milk gelled much faster with plant coagulants than with chymosin. Consequently, at low temperature it is likely that the cutting time of gels produced with plant coagulants will be considerably shorter than the cutting time of gels produced with chymosin. Plant coagulants may be useful in the production of cheeses where gelation proceeds at low temperature, while at higher temperatures, excessive proteolysis may occur impacting negatively on the texture and flavour of cheeses produced with plant coagulants.

\section{Acknowledgements}

During this research C.L.C. Esteves was supported by Calouste Gulbenkian Foundation, Portugal, and partly by the Wisconsin Center for Dairy Research.

\section{References}

Berry, G. P., \& Creamer, L. K. (1975). The association of bovine $\beta$-casein. The importance of the $\mathrm{C}$-terminal region. Biochemistry, 16, 3542-3545.

Battistotti, B., Bottazzi, V., Piccinardi, A., \& Volpato, G. (1984). Dictionary of the world cheeses. In A. Mondadori (Ed.), Glynn Christian's world guide to cheese (pp. 92-156). London, England: Ebury Press.

Bradley, R. L., Arnold, E., Barbano, D. M., Semerad, R. G., Smith, D. E., \& Vines, B. K. (1992). Chemical and physical methods. Protein. In R. T. Marshall (Ed.), Standard methods for the examination of dairy products (pp. 433-529). Washington, DC: American Public Health Association.

Carles, C., \& Ribadeau-Dumas, B. (1984). Kinetics of the action of chymosin (rennin) on some peptide bonds of $\beta$-casein. Biochemistry, 23, 6839-6843.

Carles, C., \& Ribadeau-Dumas, B. (1985). Kinetics of the action of chymosin (rennin) on a peptide bond of $\beta_{\mathrm{s} 1}$-casein. FEBS Letters, 185, 282-286.

Christen, C., \& Virasoro, E. (1935). Vegetable rennets, extraction and properties. Lait, 15, 354-363.

Creamer, L. K. (1976). A further study of the action of rennin on $\beta$ casein. New Zealand Journal of Dairy Science and Technology, 11, 30-39.

Dalgleish, D. G. (1983). Coagulation of renneted bovine casein micelles: Dependence on temperature, calcium ion concentration and ionic strength. Journal of Dairy Research, 50, 331-340.

Dalgleish, D. G., Horne, D. S., \& Law, A. J. R. (1989). Size-related differences in bovine casein micelles. Biochimica et Biophysica Acta, 991, 383-387.

Diaz, O., Gouldsworthy, A. M., \& Leaver, J. (1996). Identification of peptides from casein micelles by limited trypsinolysis. Journal of Agricultural and Food Chemistry, 44, 2517-2522.

Donnelly, W. J., McNeill, G. P., Buchheim, W., \& McGann, T. C. A. (1984). A comprehensive study of the relationship between size and protein composition in natural bovine casein micelles. Biochimica et Biophysica Acta, 789, 136-143.

EEC. (1996). Foodstuffs. Protected geographical indications and designations of origin. Official Journal of the European Union L, 163 , no. 1263.

Esteves, C. L. C. (1995). Comparative study of the biochemical characteristics of the rennets from Cynara cardunculus L., Cynara scolymus L. and Cynara humilis L. M.Sc. Thesis, University of Coimbra, Portugal.

Esteves, C. L. C., Lucey, J. A., \& Pires, E. M. V. (2001). Mathematical modelling of the formation of rennet-induced gels by plant coagulants and chymosin. Journal of Dairy Research, 68 , 499-510.

Esteves, C. L. C., Lucey, J. A., \& Pires, E. M. V. (2002). Rheological properties of milk gels made using coagulants of plant origin and chymosin. International Dairy Journal, 12, 427-434.

Esteves, C. L., Veríssimo, P. C., Faro, C. J., \& Pires, E. V. (1995) Biochemical characterization of the vegetable rennets from the flowers of cardoon: Comparison to calf rennet. Journal of Dairy Science, 78(suppl 1), 145.

Faro, C. J. F. (1991). Purification and physical-chemical characterisation of the protease of Cynara cardunculus L. Ph.D. Thesis, University of Coimbra, Portugal.

Fox, P. F. (1993). Cheese: An overview. In P. F. Fox (Ed.), Cheese: Chemistry, physics and microbiology (2nd ed.), Vol. 1 (pp. 63-110). London, England: Chapman \& Hall.

Garnier, J. (1963). Kinetic study under limited proteolysis: Action of rennet on $\beta$-casein. Biochimica et Biophysica Acta, 66, 366-377.

Heth, A. A., \& Swaisgood, H. E. (1982). Examination of casein micelle structure by a method for reversible covalent immobilization. Journal of Dairy Science, 65, 2047-2054.

Holt, C., \& Horne, D. S. (1996). The hairy casein micelle: Evolution of the concept and its implications for dairy technology. Netherlands Milk and Dairy Journal, 50, 85-111.

IDF. (1997). Bovine rennets: Determination of total milk-clotting activity. FIL-IDF Standard no. 157A. International Dairy Federation, Brussels, Belgium.

Kumosinski, T. F., Brown, E. M., \& Farrell, H. M. (1993). Threedimensional molecular modeling of bovine caseins: An energyminimized $\beta$-casein structure. Journal of Dairy Science, 76 , 931-945. 
Lagoueyte, N., Lablee, J., Lagaude, A., \& Tarodo de la Fuente, B. (1994). Temperature affects microstructure of renneted milk gels. Journal of Food Science, 5, 956-959.

Lucey, J. A., van Vliet, T., Grolle, K., Geurts, T., \& Walstra, P. (1997). Properties of acid casein gels made by acidification with glucono- $\delta$ lactone. Syneresis, permeability and microstructural properties. International Dairy Journal, 7, 389-397.

Macedo, I. M. Q., Faro, C. J. F., \& Pires, E. M. V. (1993). Specificity and kinetics of the milk-clotting enzyme from cardoon (Cynara cardunculus L.) toward bovine $\kappa$-casein. Journal of Agricultural and Food Chemistry, 41, 1537-1540.

Macedo, I. M. Q., Faro, C. J. F., \& Pires, E. M. V. (1996). Caseinolytic specificity of cardosin, an aspartic protease from the cardoon Cynara cardunculus L: Action on bovine $\alpha_{\mathrm{s}^{-}}$and $\beta$-casein and comparison with chymosin. Journal of Agricultural and Food Chemistry, 44, 42-47.

Mellema, M. (2000). Scaling relations between structure and rheology of ageing casein particle gels. Ph.D. Thesis, Wageningen Agricultural University, The Netherlands.

Payens, T. A. (1989). The enzyme-triggered coagulation of casein micelles. Advances in Colloid and Interface Science, 30, 31-69.

Ramalho-Santos, M., Veríssimo, P. C., Faro, C. J. F., \& Pires, E. M. V. (1996). Action on bovine $\alpha_{\mathrm{s} 1}$-casein of cardosins A and B, aspartic proteinases from the flowers of the cardoon Cynara cardunculus L. Biochimica et Biophysica Acta, 1297, 83-89.

SAS. (1999). SAS/STAT ${ }^{\mathrm{TM}}$ user's guide (8.0 Edition). Cary, NC: SAS Institute Inc.

Silva, S. V., Barros, R. M., \& Malcata, F. X. (2002). Hydrolysis of caseins by extracts of Cynara cardunculus precipitated by ammonium sulfate. Journal of Food Science, 67, 1746-1751.
Simões, I. I. G. (1998). Molecular characterisation of the action of cardosins $A$ and $B$ on $\beta$ - and $\kappa$-bovine caseins. M.Sc.Thesis, University of Coimbra, Portugal.

van Vliet, T. (2000). Structure and rheology of gels formed by aggregated protein particles. In K. Nishinari (Ed.), HydrocolloidsPart 1. Physical chemistry and industrial application of gels, polysaccharides, and proteins (pp. 367-377). Amsterdam: Elsevier Science.

van Hooydonk, A. C. M., Olieman, C., \& Hagedoorn, H. G. (1984). Kinetics of the chymosin-catalysed proteolysis of $\kappa$-casein in milk. Netherlands Milk and Dairy Journal, 37, 207-222.

van Vliet, T., van Dijk, H. J. M., Zoon, P., \& Walstra, P. (1991). Relation between syneresis and rheological properties of particle gels. Colloid and Polymer Science, 269, 620-627.

Vieira de Sá, F., \& Barbosa, M. (1972). Cheese-making with a vegetable rennet from Cardo (Cynara cardunculus). Journal of Dairy Research, 39, 335-343.

Walstra, P. (1999). Casein sub-micelles: Do they exist? International Dairy Journal, 9, 189-192.

Whitaker, J. R. (1994). Effect of temperature on rates of enzymecatalyzed reactions. In J. R. Whitaker (Ed.), Principles of enzymology for the food science (2nd ed) (pp. 301-328). New York: Marcel Dekker, Inc.

Zoon, P., van Vliet, T., \& Walstra, P. (1988a). Rheological properties of rennet-induced skim milk gels. 1. Introduction. Netherlands Milk and Dairy Journal, 42, 249-269.

Zoon, P., van Vliet, T., \& Walstra, P. (1988b). Rheological properties of rennet-induced skim milk gels. 2. Effect of temperature. Netherlands Milk and Dairy Journal, 42, 271-294. 